\title{
Belliculum Diplomaticum IV Thorunense
}

$\mathbb{W}$ trakcie czwartej konferencji z cyklu „Belliculum diplomaticum”, zorganizowanej w Toruniu 18 i 19 listopada 2010 r., wygłoszono dwanaście referatów. Trzech zapowiedzianych referentów nie dojechało. Oczywiście, wielka to szkoda, ale z drugiej strony dzięki temu więcej czasu można było poświęcić na dyskusję. Od poprzednich spotkań obecne odróżniało się wyjątkowym nasyceniem tematyką nowożytną. W całości lub w zdecydowanej przewadze dotyczyło jej aż osiem wystąpień, a więc dwie trzecie. Tylko po dwa referaty przypadły na średniowiecze i XIX-XX w. Ważniejsze jednak było nie to, co nowe, ale to, co stanowiło kontynuację. Już tradycyjnie bellicula są okazją do ścierania się poglądów i perspektyw badawczych dyplomatyków różnych epok, od średniowiecza po ponowoczesną współczesność wysuwającą problematykę dokumentacji elektronicznej. Nie ma drugiego takiego forum wymiany naukowej myśli dyplomatycznej.

Jeśli chodzi o różnorodność problemową, to cztery wystąpienia dotyczyły zagadnień ogólnych, również cztery skupiały się na kancelariach centralnych, dwie na kościelnych, po jednej na kancelariach sądów partykularnych i kancelariach prywatnych.

Do osiągnięć merytorycznych konferencji wypada zaliczyć wiele zaprezentowanych szczegółowych ustaleń i postulatów. Najważniejszy z dezyderatów ma wymiar ogólniejszy. Generalnie, w wielu referatach powtarzano konieczność dokonania zwrotu w badaniach dyplomatycznych ku dokumentacji. Na nowo trzeba przemyśleć następowanie po sobie systemów kancelaryjnych, ale też ich przenikanie się i długotrwałe współwystępowanie. Zwrot ku dokumentacji oznacza pracę nad zbudowaniem lepszej typologii form dyplomatycznych, a następnie badanie tych form $\mathrm{w}$ aspekcie procesu ich powstawania, ich budowy i zawartości. Dopiero to ponowne pochylenie się nad dokumentacją, swoista praca u podstaw, pozwoli na powrót do takich zagadnień, jak organizacja, personel i funkcjonowanie kancelarii. Zagadnienia te ukażą się (a przynajmniej powinny) w nowym świetle, pełniej, po uważnym wczytaniu się w dokumentację.

Otwierające konferencję wystąpienie Janusza Tandeckiego z UMK, niezaliczone tu w poczet owych dwunastu referatów, w zasadzie należałoby uznać za trzynasty referat. Autor pokusił się bowiem o przedstawienie idei spotkań z cyklu „Belliculum diplomaticum”, odbywających się na zmianę w Lublinie 
(pierwsze spotkanie w 2003 i trzecie w 2008 r.) i Toruniu (drugie spotkanie w 2005 i czwarte w 2010 r.), a także szczegółowe omówienie problematyki poprzednich trzech konferencji, zwłaszcza tych, których materiały dotychczas się nie ukazały, a więc obydwu lubelskich.

Józef Dobosz z uniwersytetu poznańskiego mówił o stanie badań nad falsyfikatami średniowiecznymi. Prezentował klasyczne podejście dyplomatyczne, mające na uwadze krytykę historyczną, autentyczność i wiarygodność dokumentów. Brakowało w referacie spojrzenia kulturowego, traktowania falsyfikatu jako faktu kulturowego, świadectwa mentalności swoich twórców i epoki, w której fałszywy dokument się pojawił, świadectwa historyczności lub ahistoryczności myślenia o przeszłości. Każdy falsyfikat niesie przecież wiarygodne informacje o wyobrażeniach swego czasu oraz o swoim twórcy i odbiorcach. Dotykamy tu istoty dyplomatyki jako nauki o dokumencie, jego powstaniu, ale też wszechstronnym funkcjonowaniu, także pozaprawnym.

Takie nowe kierunki dyplomatyki wskazała Aleksandra Jaworska z UMCS, przedstawiająca zagadnienie dokumentów iluminowanych w Polsce XV-XVIII w. W jej kwestionariuszu badawczym dokument stał się środkiem komunikacji obrazowej.

Wojciech Krawczuk z UJ, porównując Metrykę Koronną i Litewską, otworzył serię czterech wystąpień dotyczących kancelarii monarszych. Problem poruszony przez referenta ma kapitalne znaczenie i jest daleki od rozwiązania. Chodzi tu w ogóle o początkowe różnice między kancelariami koronną i wielkoksiążęcą, ich drogi rozwojowe, zwłaszcza o proces upodobniania się tych kancelarii w miarę unifikowania się Rzeczypospolitej Obojga Narodów. W tym konkretnym przypadku rodzi się pytanie, czy rzeczywiście zawsze Metryki wyglądały tak różnie, jak to jest dziś? Czy Metryka Koronna przed Stefanem Hankiewiczem nie była podobna do Metryki Litewskiej?

Referat Waldemara Chorążyczewskiego z UMK był próbą podsumowania badań nad kancelariami centralnymi dawnej Rzeczypospolitej, od strony jednak nie tego, co wiemy, ale co jeszcze wiedzieć chcielibyśmy. Autor wydzielił następujące bloki problemowe: organizacja kancelarii, jej personel, funkcjonowanie, dokument (czyli akty wydawane na zewnątrz), akta (czyli dokumentacja pozostająca w kancelarii), a także następujące kancelarie: kancelaria koronna (ogólna), kancelaria dekretowa, kancelaria Metryki Koronnej, kancelaria ruska, kancelaria pokojowa (gabinetowa), kancelaria marszałkowska, kancelarie skarbowe. Okazało się, że najbardziej palącym problemem nie jest ani organizacja kancelarii (choć o niektórych niewiele wiemy, ale dzięki metodzie porównawczej i ich podobieństwie do koronnej całkiem nieźle potrafimy sobie ją wyobrazić), ani personel (mimo luk całkiem sporo o nim wie- 
my), nawet nie funkcjonowanie, ale przede wszystkim dokument wystawiany przez różne kancelarie centralne. Dotyczy to nawet kancelarii Metryki Koronnej, która wydawała przecież ogromną liczbę ekstraktów. A ekstrakt to druga strona księgi wpisów, nie mniej od niej samej ważna. Ogólną konstatacją wystąpienia była konieczność powrotu w badaniach do żmudnej analizy dokumentów i akt.

Wystąpienie Henryka Palkija z UJ, poświęcone kancelarii koronnej Jana Szembeka, było zapowiedzią rozprawy wieńczącej wieloletnie badania autora nad kancelariami doby saskiej. Autor postawił ważne pytania. Jaki jest zakres kancelarii? Wchodzą do niej oczywiście regenci, sekretarze pieczęci, pisarze. Co jednak z referendarzami, którzy podpisują dokumenty królewskie? Na ile członkami kancelarii koronnej byli tłumacze? Czy współpraca kancelarii polskiej i litewskiej nie powodowała rodzenia się jednego centrum „rządowego”?

Blok referatów dotyczących kancelarii centralnych zamknął Aleksander Grusza z Mińska, prezentując problemy badań nad kancelarią wielkoksiążęcą litewską za panowania Zygmunta Starego. Było to kolejne wystąpienie pokazujące, że analiza dokumentacji jest obecnie podstawową drogą prowadzącą do poszerzenia wiedzy o organizacji i funkcjonowaniu kancelarii.

Janusz Łosowski z UMCS rozpoczął nową część obrad, poruszających teraz różne zagadnienia dyplomatyczne epoki nowożytnej, ale też XIX i XX w. Autor podsumował osiągnięcia i potrzeby w zakresie badań nad kancelariami terytorialnymi w dawnej Rzeczypospolitej. W referacie i w dyskusji nad nim pojawiły się kapitalne problemy. Potrzeba ogarnięcia ksiąg grodzkich inwentarzami na wzór tych, które dla Wielkopolski i Kujaw Północnych opracowała Janina Bielecka. Konieczność zastanowienia się nad aktami czynności. Brak pogłębionej typologii dokumentacji.

Następnie Ivana Ebelova z Pragi przedstawiła stan i perspektywy dyplomatyki czeskiej. Był to na pewno pouczający materiał do porównania dwóch słowiańskich dyplomatyk, ale też okazja do oderwania się na chwilę od gorącej dyskusji nad aktualnymi wyzwaniami dyplomatyki polskiej.

Zaraz jednak konferencja wróciła do zasadniczego swego wątku. Krzysztof Syta z UMK podsumował stan wiedzy, pochodzący zresztą głównie z jego własnych badań, nad kancelarią magnacką w XVIII w. Pytania i tezy stawiane przez autora wskazywały na potrzebę refleksji nad wieloma zagadnieniami kluczowymi. Co to jest kancelaria księgi wpisów? Czy brak księgi oznacza brak takiej kancelarii? Czy rejestr pism to nie jest wciąż kancelaria księgi wpisów, skoro ten rejestr decyduje o porządku dokumentacji? Należy uważniej przyjrzeć się dokumentacji, a dopiero przez jej pryzmat spojrzeć na kan- 
celarię. Najpilniejsze zadanie to chyba jednak uporządkowanie problematyki systemów kancelaryjnych.

Kontynuując jakby problematykę przenikania się i rozdziału systemów kancelaryjnych, Wiesława Kwiatkowska z UMK zajęła się kwestią ksiąg wpisów w kancelarii akt spraw. Wybrała doskonale znany sobie przykład ewangelickich ksiąg metrykalnych. Problem poruszony przez nią na pewno jednak jest dużo bardziej uniwersalny.

Robert Jop z UMCS skierował konferencję znów na grunt staropolski. Przedstawił gruntownie i nowatorsko, z wykorzystaniem wiedzy na temat prawa kościelnego i praktyki parafialnej, zagadnienie metryk Kościoła rzymskokatolickiego, z wyraźnym naciskiem na epokę przedrozbiorową.

Marek Konstankiewicz z UMCS był ostatni w szeregu referentów, ale z pewnością nie ostatni, jeśli chodzi o wagę rozpatrywanej problematyki. Znów istotne stało się pytanie o typologię systemów kancelaryjnych. Czy pojawienie się dokumentacji elektronicznej oznacza początek nowego okresu w dziejach kancelarii? Osobiście jestem rozdarty. Merytorycznie rzecz rozbierając, muszę przyznać, że nic właściwie się nie zmienia, co najwyżej kancelaria akt spraw osiąga wyższy poziom rozwoju. Z drugiej jednak strony dokumentacja elektroniczna jest tak ewidentnie, intuicyjnie różna od tradycyjnej... Oczywiście, nie tylko takie zagadnienia poruszał autor. Jako historyk i administratywista skupił się na problemie wpływu prawa administracyjnego na proces aktotwórczy, a także na konsekwencjach współczesnej praktyki urzędowej dla procesu kształcenia przyszłych archiwistów.

W sumie podczas konferencji wystąpiło trzynaście osób, nie licząc dyskutantów (na podkreślenie zasługują na pewno jako wyjątkowo aktywni polemiści Jerzy Dygdała, Tomasz Jurek, Andrzej Rachuba, Andrzej Tomczak, przy czym inne osoby niech wybaczą ich niewymienienie). Referenci reprezentowali Uniwersytet Mikołaja Kopernika w Toruniu (4 osoby), Uniwersytet im. Adama Mickiewicza w Poznaniu (1), Uniwersytet Marii Curie-Skłodowskiej w Lublinie (4), Uniwersytet Jagielloński (2). Goście z Białorusi i z Czech gwarantowali szerszy oddech dla polskiej dyplomatyki, jakąś perspektywę porównawczą, ale też integralność badań dyplomatycznych w skali ponadnarodowej.

Z całą pewnością konferencje z cyklu „Belliculum diplomaticum” czeka pomyślna przyszłość. Jest to jedyna w tej chwili okazja do tak szerokiej konfrontacji myśli dyplomatycznej w całym jej spektrum problemowym i epokowym.

Waldemar Chorażyczewski (Uniwersytet Mikołaja Kopernika w Toruniu) 